\title{
Cholesterol, HDL and Lymphatic Clearance of the Arterial Wall
}

\author{
Gerald M Lemole* \\ Adjunct Professor for Temple University's School of Medicine, USA
}

Submission: August 21, 2017; Published: August 29, 2017

*Corresponding author: Gerald M. Lemole, Adjunct Professor for Temple University's School of Medicine, Delaware, USA, Email: glemole@gmail.com

\begin{abstract}
Reverse cholesterol transport in the arterial wall was first postulated in 1981. In the last 36 years, great strides have been made in identifying the factors which cause impedance and diminished access of cholesterol laden high density lipoprotein (HDL) and foam cells to the lymphatic circulation. Initiating factors are endothelial dysfunction, oxidation of cholesterol, inflammation, monocyte migration and expression of cytokines and chemokines that inhibit cholesterol transfer and lymphatic access. Lymphatic vessels are intimately involved in this inflammatory process and the lymphatic flow is dependent on constriction, spasm, sclerosis, fluidity and external physical compression. Lifestyle changes in stress reaction, exercise and diet can profoundly influence this process.
\end{abstract}

\section{Opinion}

The lymphatic circulation as the pathway for reverse cholesterol transport (RCT) in the arterial wall was first described in 1981 [1]. In that article this route was clearly described "since HDL can transport cholesterol from tissue back to liver by way of the lymphatic's for excretion this enhanced lymphatic clearance may be the explanation for its beneficial effects", it was also postulated that slowing of lymphatic clearance increased tissue accumulation of foam cells. At that time, the role of inflammation, cytokines, cell adhesion molecules and neuropeptides had not been delineated in this disease but was prefigured in the statement, "local changes of type, amount, or physical properties of the mucopolysaccharides may represent the initial lesion \{viz. atherosclerosis\} and observation paralleling the connective tissue proliferation and increase cellularity seen in lymphstasis"[1].

Since that time, 35 years ago, great advances have been made in the identification of proteins, peptides, lipids and carbohydrates that are involved in not only the inflammatory process but in basic metabolism. In the recent decade, increasing numbers of papers have supported the role of lymphatics in reverse cholesterol transport [2-8]. These papers suggest that delay of clearance of oxidized cholesterol from the arterial wall increases inflammation, which consequently further retards cholesterol egress [68]. Several reports identify an immune involvement in the arteriosclerotic process [9-12]. Cholesterol, an essential molecule to sustain life, is transported through the capillaries to the tissue where it is utilized to create hormones, bile salts, cell membranes, pro-vitamins and other necessary metabolites [13]. However, some of it passes through dysfunctional arterial endothelium to settle in the intima [14]. There are multiple reasons for loss of integrity and endothelial penetration. Aging [15] turbulence, sheer stress, hypertensive denudation, inflammation and other metabolic disorders permit the rapidly oxidized LDL [14,16-18] to enter the intima initiating the endothelial inflammatory process involving vascular cellular adhesion molecules, and other pro-inflammatory proteins [19]. Monocytes enter the intima becoming macrophages and further the inflammatory process secreting other cytokines and chemokines [19]. The macrophages become cholesterol laden foam cells that create further inflammation unless the cholesterol can be transferred to HDL or the foam cells can migrate through the arterial wall to the lymphatic's [19].

As postulated in 1981, the development of arteriosclerosis depends on how efficiently the cholesterol can be cleared from the sub intimal space [20]. In the small arteries this does not appear as a problem however in the large and midsized arteries the lymphatics occur in the outer half of the media and in the adventitia [2]. Furthermore, the continuity of internal elastic membrane was considered an obstacle for HDL access to lymphatic circulation. As inflammation progresses, the hypertrophied 
inflamed arterial wall and foam cells create further oxidative stress producing cytokines and chemokines immobilizing the macrophages, increasing fibroblasts and collagen matrix, making access to the lymphatic system more difficult [21]. Expressed myeloperoxidase alters the discoid HDL rendering it incapable of accepting cholesterol from the foam cells [22]. Expression of neuro-polypeptides increases the inflammation, delaying reverse cholesterol transport [23-25]. Thus the foam cells play a critical but reversible role in atherogenesis and remove significant amounts of cholesterol when unimpeded [26]. Foam cells migration can be inhibited by reactive oxygen species created by NADPH oxidase in the presence of oxidized LDL [19]. However, antioxidants like resveratrol and $\mathrm{N}$-acetylcysteine can restore normal plasticity [19]. Furthermore cholesterol clearance is also accomplished by transfer of the cholesterol from the foam cells to the nascent HDL through the adenosine triphosphate by the cassette ABC A1 transport mechanism.

The longer the arterial wall is exposed to this inflammatory process, the greater the progression of atherosclerosis with [27] tissue destruction. However we know that if we increase the lymphatic flow we can improve cholesterol egress, thus decreasing arterial wall inflammation. Decreasing inflammation further improves lymphatic flow which further clears the tissue toxins and extravascular cytokines, messaging the neuro- endocrine immune system to express reparative cytokines and macrophages.

So it would seem that increasing lymphatic flow could prevent or diminish atherosclerotic plaques. It is well-known that specific lifestyle changes like increased exercise, a diet high in fruits and vegetables, and stress modification and reduction can increase lymphatic flow $[3,5,7]$. Exercise can easily triple the lymphatic flow as can deep breathing $[28,29]$. A diet high in water, flavonoids and polyphenols can also [30-33] significantly increases lymphatic flow. Lastly stress modification, can decrease the cortisol, and epinephrine levels which can prevent lymphatic sclerosis and dysfunction and constriction.

In conclusion, perhaps the most important advice we can offer to those interested in optimizing their cardiovascular health is to improve lymphatic flow by decreasing stress, increasing exercise and eating a healthful diet.

\section{References}

1. Lemole G (1981) The Role of Lymphstasis in atherogenesis. The Ann Thorac Surg 31(3): 290-293.

2. Eliska O, Eliskova M, Miller AJ (2006) The absence of lymphatics in normal and atherosclerotic coronary arteries in man: a morphologic study. Lymphology 39(2): 76-83.

3. Martel C, Wenjun Li, Brian Fulp, Andrew Platt M, Emmanuel L, et al. (2013) Lymphatic vasculature mediates macrophage reverse cholesterol transport in mice. J Clin Invest 123(4): 1571-1579.

4. Randolph G (2008) Emigration of monocyte-derived cells to lymph nodes during resolution of inflammation and its failure in atherosclerosis. Curr Opin Lipidol 19(5): 462-468.

5. Martel C, Randolph G (2013) Atherosclerosis and transit of HDL through the lymphatic vasculature. Curr atheroscler Rep 15(9): 354.
6. Lim HY, Thiam CH, Yeo KP, Bisoendial R, Hii CS, et al. (2013) Lymphatic vessels are essential for the removal of cholesterol from peripheral tissues by SR-BI-mediated transport of HDL. Cell Metab 17(5): 671684 .

7. Vuorio T, Nurmi H, Moulton K, Kurkipuro J, Robciuc MR, et al. (2014) Lymphatic vessel insufficiency in hypercholesterolemic mice alters lipoprotein levels and promotes atherogenesis. Arterioscler Thromb Vasc Biol 34(6): 1162-1170.

8. Kutkut I, Meens MJ, McKee TA, Bochaton-Piallat ML, Kwak BR, et al. (2015) Lymphatic vessel insufficiency in hypercholesterolemic mice alters lipoprotein levels and promotes atherogenesis. Eur J Clin Invest 45(1): 100-108.

9. Wilhelm AJ, Zabalawi M, Grayson JM, Weant AE, Major AS, et al. (2009) Apolipoprotein A-I and its role in lymphocyte cholesterol homeostasis and autoimmunity. Arterioscler Thromb Vasc Biol 29(6): 843-849.

10. Liao S, Cheng G, Conner DA, Huang Y, Kucherlapati RS, et al. (2011) Impaired lymphatic contraction associated with immunosuppression. Proc Natl Acad Sci U S A 108(46): 18784-18789.

11. Bobryshev YV, Lord RS (1998) Mapping of vascular dendritic cells in atherosclerotic arteries suggests their involvement in local immuneinflammatory reactions. Cardiovasc Res 37(3): 799-810.

12. Reiss AB, Wan DW, Anwar K, Merrill JT, Wirkowski PA, et al. (2009) Enhanced CD36 scavenger receptor expression in THP-1 human monocytes in the presence of lupus plasma: linking autoimmunity and atherosclerosis. Exp Biol Med (Maywood) 234(3): 354-360.

13. Lecerfa JM, De Lorgeril M (2001) Dietary cholesterol: from physiology to cardiovascular risk. Br J Nutr 106(1): 6-14.

14. Pfenniger A, Chanson M, Kwak BR (2013) Connexins in atherosclerosis. Biochim Biophys Acta 1828(1): 157-166.

15. Kleinstreuer C, Hyun S, Buchanan JR, Longest PW, Archie JP, et al. (2001) Hemodynamic parameters and early intimal thickening in branching blood vessels. Crit Rev Biomed En 29(1): 1-64.

16. Dabagh M, Jalali P, Tarbell JM (2009) The transport of LDL across the deformable arterial wall: the effect of endothelial cell turnover and intimal deformation under hypertension. Am J Physiol Heart Circ Physiol 297(3): H983-H996.

17. Davies MJ, Woolf N, Rowles PM, Pepper J (1988) Morphology of the endothelium over atherosclerotic plaques in human coronary arteries. Br Heart J 60(6): 459-464.

18. Lamarche B, St-Pierre AC, Ruel IL, Cantin B, Dagenais GR, et al. (2001) A prospective, population-based study of low density lipoprotein particle size as a risk factor for ischemic heart disease in men. Can J Cardiol 17(8): 859-865.

19. Park YM, Febbraio M, Silverstein RL (2009) CD36 modulates migration of mouse and human macrophages in response to oxidized LDL and may contribute to macrophage trapping in the arterial intima. J Clin Invest 119(1): 136-145.

20. Rohatgi A, Khera A, Berry JD, Givens EG, Ayers CR, et al. (2014) Cholesterol efflux capacity and incident cardiovascular events. N Engl J Med 371(25): 2383-2393.

21. Gerszten RE, Tager AM (2012) The monocyte in atherosclerosisshould I stay or should I go now? N Engl J Med 366(18): 1734-1736.

22. Shao B, Tang C, Sinha A, Mayer PS, Davenport GD, et al. (2014) Humans with atherosclerosis have impaired ABCA1 cholesterol efflux and enhanced high-density lipoprotein oxidation by myeloperoxidase. Circ Res 114(11): 1733-1742.

23. Van Gils JM, Derby MC, Fernandes LR, Ramkhelawon B, TD Ray, et al. (2012) The neuroimmune guidance cue netrin-1 promotes atherosclerosis by inhibiting the emigration of macrophages from plaques. Nat Immunol 13(2): 136-143 
24. Lagraauw HM, Westra MM, Bot M, Wezel A, Van Santbrink PJ, et al. (2014) Vascular neuropeptide Y contributes to atherosclerotic plaque progression and perivascular mast cell activation. Atherosclerosis 235(1): 196-203.

25. Wanschel A, Seibert T, Hewing B, Ramkhelawon B, Ray TD, et al (2013) Neuroimmune guidance cue Semaphorin 3E is expressed in atherosclerotic plaques and regulates macrophage retention. Arterioscler Thromb Vasc Biol 33(5): 886-893.

26. Llodrá J, Angeli V, Liu J, Trogan E, Fisher EA, et al. (2004) Emigration of monocyte-derived cells from atherosclerotic lesions characterizes regressive, but not progressive, plaques. Proc Natl Acad Sci USA 101(32): 11779-11784.

27. Lemole G (2016) Athergenesis and Lymphstasis...Connect in the Dots. Lymphology 49(1): 8-14.

28. Geffken DF, Cushman M, Burke GL, Polak JF, Sakkinen PA, et al. (2001) Association between physical activity and markers of inflammation in a healthy elderly population. Am J Epidemiol 153(3): 242-50.
29. Desai P, Williams AG, Prajapati P, Downey HF (2010) Lymph flow in instrumented dogs varies with exercise intensity. Lymphat Res Biol 8(3): 143-148.

30. Fung T, Hu F (2003) Plant-based diets: what should be on the plate? Am J Clin Nutr 78(3): 357-358.

31. Willett WC (1994) Diet and health: what should we eat? Science 264(5158): 532-537.

32. Ginter E, Simko V (2015) Recent data on Mediterranean diet, cardiovascular disease, cancer, diabetes and life expectancy. Bratisl Lek Listy 116(6): 346-348.

33. Chainani-Wu N, Weidner G, Purnell DM, Frenda S, Merritt-Worden T, et al. (2011) Changes in emerging cardiac biomarkers after an intensive lifestyle intervention. Am J Cardiol 108(4): 498-507.

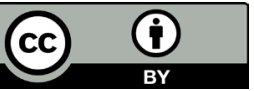

his work is licensed under Creative Commons Attribution 4.0 License

DOI: $10.19080 / J O C C T .2017 .07 .555718$

\section{Your next submission with Juniper Publishers} will reach you the below assets

- Quality Editorial service

- Swift Peer Review

- Reprints availability

- E-prints Service

- Manuscript Podcast for convenient understanding

- Global attainment for your research

- Manuscript accessibility in different formats

( Pdf, E-pub, Full Text, Audio)

- Unceasing customer service

Track the below URL for one-step submission https://juniperpublishers.com/online-submission.php 